Огляди літератури, оригінальні дослідження, погляд на проблему, випадок з практики, короткі повідомлення УДК 616.411:612.123:612.015.11:[616-005.1+616.748-005.4]:615.214.3-092.9

DOI 10.11603/1811-2471.2020.v.i4.11771

\title{
ДИНАМІКА АКТИВНОСТІ ПРОЦЕСІВ ЛІПІДНОЇ ПЕРОКСИДАЦІЇ В СЕЛЕЗІНЦІ ПІД ВПЛИВОМ ГОСТРОЇ КРОВОВТРАТИ, УСКЛАДНЕНОӦ ІШЕМІЄЮ-РЕПЕРФУЗІЄЮ КІНЦІВКИ, ТА Ï̈ КОРЕКЦІЯ КАРБАЦЕТАМОМ
}

\author{
@І. В. Яворська, І. Я. Господарський
}

Тернопільський національний медичний університет імені І. Я. Горбачевського Моз України

РЕЗЮмЕ. Застосування турнікета за умов масивної зовнішньої кровотечі $є$ основним засобом рятування поранених і постраждалих у результаті поранень магістральних судин кінцівок з безпечним терміном до двох годин. Одночасно доведено, що двогодинна повна ішемія-реперфузія кінцівки зумовлює активацію процесів пероксидного окиснення ліпідів (ПОЛ) у внутрішніх органах, що, за умов гострої крововтрати, сприяє розвитку поліорганної недостатності. Однак, за умов гострої крововтрати, ускладненої ішемією-реперфузією кінцівки, інтенсивність ПОЛ практично не досліджена в селезінці.

Мета - з'ясувати вплив гострої крововтрати, ускладненої ішемією-реперфузією кінцівки, на активність процесів Пол у селезінці та оцінити корегувальну ефективність карбацетаму.

Матеріал і методи. В експериментах використано 108 нелінійних щурів-самців масою 200-220 г. Усі експерименти виконані під тіопентало-натрієвим наркозом. У тварин моделювали ішемію-реперфузію кінцівки, гостру крововтрату та поєднували ці ушкодження. В окремій групі проводили корекцію виявлених порушень карбацетамом. Через 1 і 2 години, а також через 1, 7 і 14 діб у селезінці піддослідних тварин визначали вміст дієнових кон'югатів (ДК) та вміст реагентів до тіобарбітурової кислоти (ТБК-активні продукти ПОЛ).

Результати. Встановлено, що за умов ішемії-реперфузії кінцівки, гострої крововтрати та їх поєднання має місце посилення процесів ліпідної пероксидації в селезінці, що виявляється зростанням вмісту ДК та ТБК-активних продуктів ПОЛ. Загальною закономірністю інтенсифікації ПОЛ у селезінці $є$ досягнення максимального рівня через 1 добу з наступним зниженням. Додаткове ускладнення гострої крововтрати ішемією-реперфузією кінцівки супроводжується істотно більшим зростанням інтенсивності пОЛ у селезінці, порівняно з їх окремим моделюванням. За умов корекції карбацетамом у тварин із гострою крововтратою, ускладненою ішемією-реперфузією кінцівки, активність процесів ліпідної пероксидації в селезінці зменшувалася, що через 7 і 14 діб проявлялося істотно нижчим вмістом досліджуваних показників ПОЛ. Отже, карбацетам чинить системний антиоксидантний вплив, що ставить його в ряд перспективних засобів зниження проявів оксидативних порушень у внутрішніх органах за умов гострої крововтрати, ускладненої ішемією-реперфузією кінцівки, та профілактики розвитку поліорганної недостатності.

Висновки. Ішемія-реперфузія кінцівки сприяє посиленню процесів ліпідної пероксидації в селезінці, зумовлених гострою крововтратою, що супроводжується статистично вірогідно більшим зростанням вмісту ДК через 2 год і 14 діб експерименту та ТБК-активних продуктів ПОЛ - через 1, 7 і 14 діб, порівняно з тваринами, яким моделювали лише гостру крововтрату. Застосування карбацетаму в дозі 5 мг·кг $\Gamma^{-1}$ внутрішньоочеревинно чинить виражений антиоксидантний вплив і через 7 та 14 діб сприяє меншому зростанню в селезінці ДК та ТБК-активних продуктів ПОЛ.

КлючовІ СлОВА: гостра крововтрата; ішемія-реперфузія кінцівки; селезінка; ліпідна пероксидація; карбацетам.

Вступ. Сьогодні переконливо доведено, що застосування турнікета при масивній зовнішній кровотечі $є$ основним засобом рятування поранених і постраждалих за умов поранень магістральних судин кінцівок [1]. Однак дотепер існують розбіжності щодо визначення тривалості безпечної повної турнікетної ішемії кінцівок. В існуючих настановах з тактичної медицини зазначають, що граничним терміном для відновлення кровотоку в кінцівках $€ 2$ години [2]. Разом з тим, в окремих експериментальних дослідженнях показано, що двогодинна ішемія кінцівки щурів сприяє активації процесів пероксидного окиснення ліпідів (ПОЛ) та супроводжується вираженими судинними реакціями в м'яких тканинах проксимальніше накладання джгута [3]. Автори констатують, що за цих умов посилення процесів ПОЛ та виснаження антиоксидантного захисту мали системний характер й повільно досягали рівня контролю до 14 доби експе-

рименту. Аналогічні порушення виникали у внутрішніх органах [4], зокрема в печінці [5], нирках [6], тонкій кишці [7] та легенях [8]. Автори довели, що моделювання двогодинної ішемії-реперфузії кінцівки на тлі гострої крововтрати суттєво поглиблювало порушення, викликані лише крововтратою, які не нормалізувалися до 14 доби. Припускають, що додаткове навантаження ендотоксинами ішемізованої кінцівки, яке поглиблюється за умов реперфузії, суттєво обтяжує сукупність порушень, зумовлених гострою крововтратою.

Одним із органів, який відіграє важливу компенсаторну роль за умов гострої крововтрати, $\epsilon$ селезінка. За рахунок депонувальної функції селезінка може впливати на стан центральної гемодинаміки й одночасно стимулювати еритропоез [9]. Однак, за умов гострої крововтрати, ускладненої ішемією-реперфузією кінцівки, інтенсивність ПОЛ у селезінці практично не досліджена. 
Огляди літератури, оригінальні дослідження, погляд на проблему, випадок з практики, короткі повідомлення Немає даних про ефективність за цих умов карбацетаму, який, за даними окремих авторів $[5,6,8]$, має антиоксидантну активність і позитивно впливає на стан печінки, нирок і легень.

Мета - з'ясувати вплив гострої крововтрати, ускладненої ішемією-реперфузією кінцівки, на активність процесів ПОЛ у селезінці та оцінити корегувальну ефективність карбацетаму.

Матеріал і методи дослідження. В експериментах використано 108 нелінійних щурів-самців масою 200-220 г. Усі експерименти виконано з дотриманням правил «Європейської конвенції з захисту хребетних тварин, яких використовують 3 експериментальною та іншою науковою метою» (European Convention, 1984).

Піддослідних тварин поділили на чотири групи: контрольну та чотири дослідних (по 6 щурів у групі). Усі втручання виконані за умов тіопенталнатрієвого наркозу (40 мгхкг ${ }^{-1}$ маси тіла). У першій дослідній групі тваринам моделювали ішеміюреперфузію кінцівки шляхом накладання проксимально на ліву лапку джгута на 120 хв. Застосовували смужку еластичного джгута «SWAT-T» (США) завширшки 10 мм. Такий джгут має мінімальний негативний вплив на підлеглі тканини і забезпечує сталу повну ішемію впродовж терміну експерименту $[10,11]$. Ефективність застосування джгута контролювали реографічним методом. У другій дослідній групі шляхом пересікання стегнової вени моделювали гостру крововтрату в обсязі 20-22 \% об'єму циркулюючої крові.

У третій дослідній групі ці ушкодження поєднували. У четвертій дослідній групі тваринам із гострою крововтратою, ускладненою ішемією-ре-

перфузією кінцівки, з метою корекції внутрішньоочеревинно вводили карбацетам (Інститут фізикоорганічної хімії та вуглехімії НАН України, Донецьк) у дозі 5 мг на кілограм маси тварини [7].

В умовах тіопентал-натрієвого наркозу тварин першої, другої і третьої дослідних груп виводили з експерименту через 1 і 2 години, а також через 1, 7 i 14 діб, тварин четвертої дослідної групи - через 7 і 14 діб. Тварин контрольної групи лише вводили в наркоз, застосовуючи еквівалентну дозу тіопенталу натрію, накладали джгут без припинення кровотоку і згодом виводили з експерименту через 2 год.

У селезінці визначали вміст дієнових кон'югатів (ДК) та реагентів до тіобарбітурової кислоти (ТБК-активних продуктів ПОЛ), які є стійким маркером зростання активності ПОЛ [12].

Вірогідність відмінностей між контрольною і дослідними групами оцінювали з використанням непараметричного критерію Манна - Уітні. Відмінності вважали істинними при вірогідності нульової гіпотези менше 5 \% $(p<0,05)$.

Результати й обговорення. Як видно з даних, наведених у таблиці 1, за умов ішемії-реперфузії кінцівки вміст у селезінці ДК зростав. Через 2 год, 1 і 7 діб показник ставав статистично значущим, порівняно з контролем (відповідно на 38,0, 57,6 і 47,8 \%, p<0,05). У динаміці показник досягав максимуму через 2 год, істотно перевищував величину на 1 год спостереження $(p<0,05)$ i утримувався на такому ж рівні до 7 доби експерименту ( $p>0,05)$. До 14 доби показник знижувався, ставав статистично вірогідно меншим, ніж через 1 год, 1 і 7 діб експерименту $(p<0,05)$ та досягав рівня контролю ( $p>0,05)$.

Таблиця 1. Вміст дієнових кон'югатів у селезінці (ум. од.• $\left\ulcorner^{-1}\right)$ після гострої крововтрати, ускладненої ішемієюреперфузією кінцівки ((Me (LQ; UQ) - медіана (нижній і верхній квартилі))

\begin{tabular}{|c|c|c|c|c|c|}
\hline \multirow{2}{*}{ Дослідна група } & \multicolumn{5}{|c|}{ Термін реперфузійного періоду } \\
\hline & 1 год & 2 год & 1 доба & 7 доба & 14 доба \\
\hline \multicolumn{6}{|c|}{ Контроль $=0,92(0,89 ; 0,96)(n=6)$} \\
\hline $\begin{array}{l}\text { Група } 1 \\
\text { Ішемія-реперфузія }\end{array}$ & $\begin{array}{c}0,96 \\
(0,90 ; 1,06) \\
(n=6)\end{array}$ & $\begin{array}{c}1,27^{* 1 r} \\
(1,16 ; 1,40) \\
(n=6)\end{array}$ & $\begin{array}{c}1,45^{* 1 r} \\
(1,39 ; 1,53) \\
(n=6)\end{array}$ & $\begin{array}{c}1,36^{* 15} \\
(1,33 ; 1,52) \\
(n=6)\end{array}$ & $\begin{array}{c}1,02^{2 г, 11,7 д} \\
(0,91 ; 1,10) \\
(n=6)\end{array}$ \\
\hline $\begin{array}{l}\text { Група } 2 \\
\text { Крововтрата }\end{array}$ & $\begin{array}{c}1,24^{*} \\
(1,19 ; 1,34) \\
(n=6)\end{array}$ & $\begin{array}{c}1,48^{* 1 r} \\
(1,44 ; 1,54) \\
(n=6)\end{array}$ & $\begin{array}{c}2,13^{* 11,2 r} \\
(2,02 ; 2,24) \\
(n=6)\end{array}$ & $\begin{array}{c}1,77^{\star 11,2 r, 14} \\
(1,60 ; 1,89) \\
(n=6)\end{array}$ & $\begin{array}{c}1,53^{* 1 \Gamma, 1 д} \\
(1,46 ; 1,59) \\
(n=6)\end{array}$ \\
\hline $\begin{array}{l}\text { Група } 3 \\
\text { Ішемія-реперфузія + } \\
\text { крововтрата }\end{array}$ & $\begin{array}{c}1,35^{*} \\
(1,31 ; 1,46) \\
(n=6)\end{array}$ & $\begin{array}{c}1,68^{* 1 r} \\
(1,59 ; 1,73) \\
(n=6)\end{array}$ & $\begin{array}{c}2,46^{* 11,2 r} \\
(2,38 ; 2,56) \\
(n=6)\end{array}$ & $\begin{array}{c}2,04^{* 11,2 r, 14} \\
(1,94 ; 2,11) \\
(n=6)\end{array}$ & $\begin{array}{c}1,97^{* 11,1 A, 7 \AA} \\
(1,66 ; 2,19) \\
(n=6)\end{array}$ \\
\hline$P_{1-2}$ & $<0,05$ & $<0,05$ & $<0,05$ & $<0,05$ & $<0,05$ \\
\hline$P_{1-3}$ & $<0,05$ & $<0,05$ & $<0,05$ & $<0,05$ & $<0,05$ \\
\hline$P_{2-3}$ & $>0,05$ & $<0,05$ & $>0,05$ & $>0,05$ & $<0,05$ \\
\hline
\end{tabular}

Примітки. Тут і в табл. 2: $1 .{ }^{*}$ - відмінності стосовно контрольної групи статистично вірогідні $(p<0,05) ; 2$. р $_{1-2}-$ вірогідність

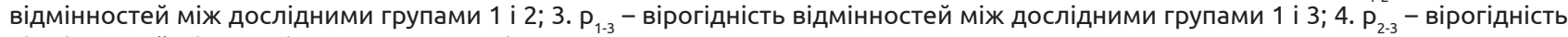
відмінностей між дослідними групами 1 і 3. 
Огляди літератури, оригінальні дослідження, погляд на проблему, випадок з практики, короткі повідомлення

За умов гострої крововтрати вміст ДК у селезінці в усі терміни спостереження істотно перевищував контроль $(p<0,05)$. Показник досягав максимуму через 1 добу експерименту, ставав у 2,32 раза більшим від контролю $(p<0,05)$ та статистично вірогідно перевищував попередні терміни спостереження $(p<0,05)$. Згодом цей показник знижувався, проте через 14 діб все ще перевищував контроль на $66,3 \%(p<0,05)$.

Ускладнення гострої крововтрати ішемією-реперфузією кінцівки супроводжувалося ще більшими порушеннями вмісту ДК у селезінці. Показник у всі терміни істотно перевищував контроль $(p<0,05)$. Через 1 добу показник досягав максимуму і ставав у 2,56 раза більшим, ніж у контролі $(p<0,05)$. До 14 доби показник знижувався, проте залишався в 2,14 раза більшим, ніж у контролі $(p<0,05)$.

Порівняння дослідних груп між собою в динаміці експерименту показало, що за умов гострої крововтрати та її поєднання з ішемією-реперфузією кінцівки вміст у селезінці ДК у всі терміни експерименту статистично вірогідно перевищував аналогічний показник дослідної групи, в якій моделювали лише ішемію-реперфузію кінцівки $\left(p_{1-2}<0,05 ; p_{1-3}<0,05\right)$. У групі, в якій поєднували гостру крововтрату та ішемію-реперфузію кінцівки, показник через 2 год, 1, 7 та 14 діб був більшим, порівняно із групою, в якій моделювали лише гостру крововтрату (відповідно на 13,5, 15,4, 13,6 та $\left.28,8 \%, \mathrm{p}_{2-3}<0,05\right)$.

Вміст у селезінці ТБК-активних продуктів ПОЛ (табл. 2) після моделювання лише ішемії-реперфузії кінцівки, порівняно з контролем через 2 год та 1 добу експерименту, статистично вірогідно зростав (відповідно на 13,5 і 19,0\%, p<0,05). Починаючи з 7 доби показник у цій групі знижувався й досягав рівня контролю (p>0,05). У динаміці експерименту вміст у селезінці ТБК-активних продуктів досягав максимуму через 1 добу, що виявилося статистично вірогідним, порівняно з 1 год експерименту $(p<0,05)$. Через 7 i 14 діб показник ставав істотно меншим, порівняно з 1 добою $(p<0,05)$.

Таблиця 2. Вміст ТБК-активних продуктів ПОЛ у селезінці (мкмоль·кг¹) після гострої крововтрати, ускладненої ішемією-реперфузією кінцівки ((Me (LQ; UQ) - медіана (нижній і верхній квартилі))

\begin{tabular}{|c|c|c|c|c|c|}
\hline \multirow{2}{*}{ Дослідна група } & \multicolumn{5}{|c|}{ Термін реперфузійного періоду } \\
\hline & 1 год & 2 год & 1 доба & 7 доба & 14 доба \\
\hline \multicolumn{6}{|c|}{ Контроль $=2,52(2,36 ; 2,66)(n=6)$} \\
\hline $\begin{array}{l}\text { Група } 1 \\
\text { Ішемія-реперфузія }\end{array}$ & $\begin{array}{c}2,70 \\
(2,65 ; 2,82) \\
(n=6)\end{array}$ & $\begin{array}{c}2,86^{*} \\
(2,71 ; 3,01) \\
(n=6)\end{array}$ & $\begin{array}{c}3,00 * 1 r \\
(2,91 ; 3,16) \\
(n=6)\end{array}$ & $\begin{array}{c}2,75^{1 д} \\
(2,64 ; 2,86) \\
(n=6)\end{array}$ & $\begin{array}{c}2,58^{1 д} \\
(2,35 ; 2,73) \\
(n=6)\end{array}$ \\
\hline $\begin{array}{l}\text { Група } 2 \\
\text { Крововтрата }\end{array}$ & $\begin{array}{c}2,92^{*} \\
(2,78 ; 2,96) \\
(n=6)\end{array}$ & $\begin{array}{c}3,19^{* 11} \\
(2,99 ; 3,36) \\
(n=6)\end{array}$ & $\begin{array}{c}3,86^{* 11,2 r} \\
(3,54 ; 4,05) \\
(n=6)\end{array}$ & $\begin{array}{c}3,43^{* 1,1,1 д} \\
(3,32 ; 3,46) \\
(n=6)\end{array}$ & $\begin{array}{c}2,94^{* 1 \text { म, } 7 \text { म }} \\
(2,79 ; 3,19) \\
(n=6)\end{array}$ \\
\hline $\begin{array}{l}\text { Група } 3 \\
\text { Ішемія-реперфузія+ } \\
\text { крововтрата }\end{array}$ & $\begin{array}{c}3,13^{*} \\
(2,97 ; 3,25) \\
(n=6) \\
\end{array}$ & $\begin{array}{c}3,51^{* 11} \\
(3,35 ; 3,61) \\
(n=6) \\
\end{array}$ & $\begin{array}{c}5,34^{* 11,2 r} \\
(5,04 ; 5,77) \\
(n=6) \\
\end{array}$ & $\begin{array}{c}4,68^{* 1 r, 2\ulcorner} \\
(4,33 ; 4,99) \\
(n=6)\end{array}$ & $\begin{array}{c}3,83^{* 11,11,7 \AA} \\
(3,65 ; 4,18) \\
(n=6) \\
\end{array}$ \\
\hline$p_{1-2}$ & $>0,05$ & $<0,05$ & $<0,05$ & $<0,05$ & $<0,05$ \\
\hline$p_{1-3}$ & $<0,05$ & $<0,05$ & $<0,05$ & $<0,05$ & $<0,05$ \\
\hline$P_{2-3}$ & $>0,05$ & $>0,05$ & $<0,05$ & $<0,05$ & $<0,05$ \\
\hline
\end{tabular}

Після моделювання гострої крововтрати вміст у селезінці ТБК-активних продуктів у всі терміни експерименту був статистично вірогідно більшим, ніж у контролі (р<0,05). Показник до 1 доби зростав. У цей термін він перевищував контроль на $53,2 \%(p<0,05)$ та був істотно більшим, порівняно 3 попередніми термінами спостереження $(p<0,05)$. В подальшому показник знижувався. Через 14 діб він ставав істотно меншим, ніж через 1 і 7 діб ( $><0,05)$, проте залишався на 16,7 \% більшим, ніж у контролі $(p<0,05)$.

Ще більші порушення виникали з умов поєднання гострої крововтрати та ішемії-реперфузії кінцівки. Через 1 год, порівняно з контролем, вміст у селезінці ТБК-активних продуктів ПОЛ був більшим на 24,2 \%, через 2 год - на 55,6 \%, через
1 добу - на 111,7 \%, через 7 діб - на 85,7 \%, через 14 діб - на 52,0 \% (p<0,05). У динаміці показник досягав максимуму через 1 добу експерименту й був істотно більшим, ніж через 1 і 2 год (відповідно на 70,6 та 36,2 \%, р<0,05). До 14 діб показник знижувався й ставав статистично вірогідно меншим, ніж через 1 і 7 діб (відповідно на 28,3 і 18,2 \%, p<0,05).

Порівняння дослідних груп між собою показало, що після моделювання гострої крововтрати вміст у селезінці ТБК-активних продуктів починаючи з 2 год експерименту був істотно більшим, ніж після моделювання лише ішемії-реперфузії кінцівки $\left(p_{1-2}<0,05\right)$. Поєднання гострої крововтрати та ішемії-реперфузії кінцівки зумовлювало ще більше зростання в селезінці вмісту ТБК-активних продуктів, що у всі терміни виявилося істотно біль- 
Огляди літератури, оригінальні дослідження, погляд на проблему, випадок з практики, короткі повідомлення шим, ніж у групі, в якій моделювали лише ішеміюреперфузію кінцівки $\left(\mathrm{p}_{1-3}<0,05\right)$ та через 2 год, $1,7 \mathrm{i}$ 14 діб порівняно з групою, в якій моделювали лише гостру крововтрату (відповідно на 22,8, 38,3, 36,4 та $\left.30,2 \%, p_{2-3}<0,05\right)$.

Застосування тваринам з гострою крововтратою, ускладненою ішемією-реперфузією кінцівки, карбацетаму протягом 7 діб, порівняно з тваринами без корекції (рис. 1), зумовлювало статистично вірогідне зниження вмісту ДК в селезінці на 14,0 \%, через 14 діб - на 22,3 \% (р<0,05). Вміст ТБК-активних продуктів ПОЛ (рис. 2) після застосування карбацетаму через 7 діб знижувався на 24,4\%, через 14 діб - на 20,6 \% ( $<<0,05)$.

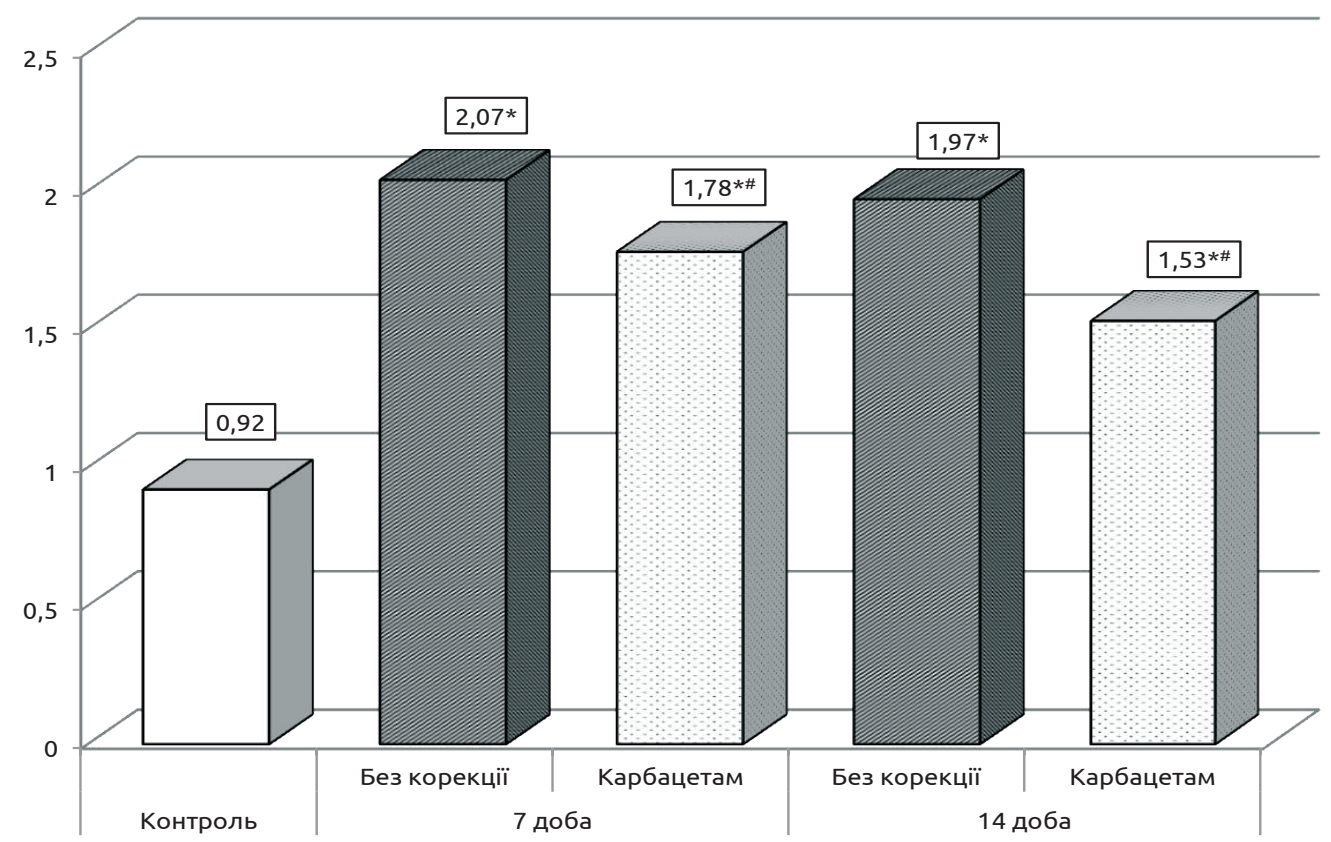

Рис. 1. Вплив карбацетаму на вміст дієнових кон'югатів у селезінці (ум. од. $\left\ulcorner^{1}\right.$ ) після гострої крововтрати, ускладненої ішемією-реперфузією кінцівки.

Примітка. Тут і на рис. 2: * - відмінності стосовно контрольної групи статистично вірогідні; $\mathbf{p}<0,05$; \# - відмінності стосовно групи без корекції статистично вірогідні, p<0,05.

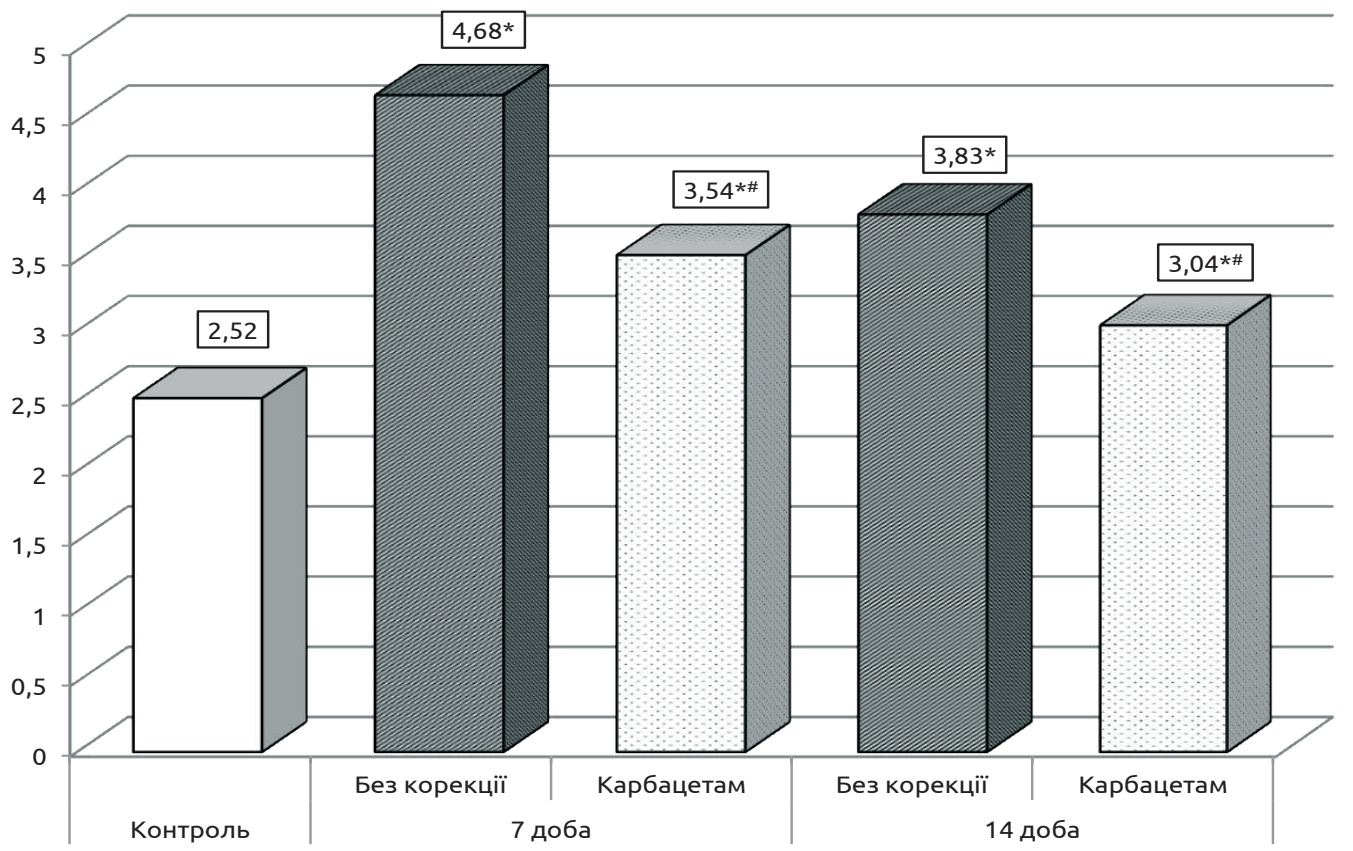

Рис. 2. Вплив карбацетаму на вміст ТБК-активних продуктів пол у селезінці (мкмоль-кгํㅜ) після гострої крововтрати, ускладненої ішемією-реперфузією кінцівки. 
Огляди літератури, оригінальні дослідження, погляд на проблему, випадок з практики, короткі повідомлення

Отримані результати свідчать про те, що за умов ішемії-реперфузії кінцівки, гострої крововтрати та їх поєднання має місце посилення процесів ліпідної пероксидації в селезінці, що виявили на основі зростання вмісту ДК та ТБК-активних продуктів ПОЛ. Загальною закономірністю інтенсифікації ПОЛ у селезінці є досягнення максимального рівня через 1 добу з наступним зниженням. Встановлено, що за умов лише ішемії-реперфузії кінцівки показники до 14 доби досягають рівня контролю. Цей результат підтверджує думку ряду авторів про те, що порушення, викликані двогодинною ішемією кінцівки, в реперфузійному періоді повністю компенсуються організмом і знаходяться в межах гомеостатичного регулювання [3, 10].

Водночас за умов гострої крововтрати в межах 20-22 \% ОЦК активація процесів ПОЛ є більш вираженою у всі терміни спостереження. До 14 доби показники не досягають рівня контролю. Отримані результати зумовлені розвитком гемічної гіпоксії, яка торкається практично всіх органів, в тому числі селезінки. Додаткове ускладнення гострої крововтрати ішемією-реперфузією кінцівки супроводжується ще більшими порушеннями ПОЛ у селезінці. Можна припустити, що має місце нашарування патогенних механізмів обох втручань, що констатується у ряді досліджень [5, 6, 8]. Основними з них $\epsilon$ поява активних форм кисню та токсичних метаболітів у реперфузованій кінцівці, які, потрапляючи в системний кровотік, здатні негативно впливати на життєво важливі органи $[13,14]$.

Отримані нами результати дозволяють припустити, що активація ПОЛ у селезінці за умов гострої крововтрати, ускладненої ішемією-реперфузією кінцівки, може призвести до деструкції мембран клітинних компонентів лімфоїдної тканини селезінки та порушення клітинної і гуморальної імунної відповіді, вродженого й набутого імунітету, кількісного та якісного складу імуноцитів крові, лімфи та інших лімфоїдних органів [1517], а також екстрамедулярного кровотворення, що має місце у гризунів [18].

За умов корекції карбацетамом у тварин із гострою крововтратою, ускладненою ішемією-реперфузією кінцівки, активність процесів ліпідної пероксидації в селезінці зменшувалася, що проявлялося істотно нижчим вмістом первинних і вторинних продуктів ПОЛ, порівняно з тваринами без корекції. Аналогічні результати були отримані й іншими авторами, які довели ефективність препарату за ступенем зниження активності ПОЛ у нирках [6], печінці [5] та легенях [8]. Отже, карбацетам чинить системний антиоксидантний вплив, що ставить його в ряд перспективних засобів для зниження проявів оксидативних порушень у внутрішніх органах за умов гострої крововтрати, ускладненої ішемією-реперфузією кінцівки, та профілактики розвитку поліорганної недостатності.

Висновки. 1. Ішемія-реперфузія кінцівки сприяє посиленню процесів ліпідної пероксидації в селезінці, зумовлених гострою крововтратою, що супроводжується статистично вірогідно більшим зростанням вмісту ДК через 2 год і 14 діб експерименту та ТБК-активних продуктів ПОЛ - через 1, 7 i 14 діб, порівняно з тваринами, яким моделювали лише гостру крововтрату.

2. Застосування карбацетаму в дозі $5 \mathrm{Mr} \cdot \mathrm{Kr}^{-1}$ внутрішньоочеревинно чинить виражений антиоксидантний вплив і через 7 та 14 діб сприяє меншому зростанню в селезінці рівнів ДК та ТБКактивних продуктів ПОЛ.

Перспективи подальших досліджень. У подальшому доцільно встановити характер імунологічних порушень за умов гострої крововтрати та визначити їх взаємозв'язок із рівнем ПОЛ у селезінці.

\section{ЛІТЕРАТУРА}

1. Elster E. Implications of combat casualty care for mass casualty events / E. A. Elster, K. B. Frank, E. R. Todd // JAMA. - 2013. - Vol. 310 (5). - P. 475-476.

2. Efficacy of prehospital application of tourniquets and hemostatic dressings to control traumatic external hemorrhage [Electronic resource]. - Access mode : https:// trid.trb.org/view/1489860.

3. Аналіз змін структури м'язової тканини та біохімічних показників сироватки крові при розвитку ішемічно-реперфузійного синдрому (експериментальне дослідження) / А. Т. Телев'як, П. Р. Сельський, Т. О. Вересюк, А. Ф. Слива : з6. матеріалів X Конгресу патологів України «Перспективи розвитку сучасної патології», 27-28 вересня 2018 р., Івано-Франківськ-Яремче. - Ів.Франк., 2018. - С. 176-177.
4. Volotovska N. V. Changes in the glutathione system's activity of internal organs in the first hours of experimental limb ischemia-reperfusion syndrome, combined with blood loss and mechanical injury / N. V. Volotovska, T. C. Nhokwara, I. V. Zhulkevych // Здобутки клініч. i експерим. медицини. - 2019. - № 1. - С. 23-27.

5. Горбань І. І. Вплив гострої крововтрати, ускладненої ішемією-реперфузією кінцівки, на антиоксидантно-прооксидантний баланс печінки та його корекція карбацетамом / І. І. Горбань // Здобутки клінічної і експериментальної медицини. - 2020. - № 2. - С. 93-100.

6. Шацький В. В. Динаміка антиоксидантно-прооксидантного балансу кіркового і мозкового шарів нирки після гострої крововтрати, ускладненої ішемією-реперфузією кінцівки, та його корекція карбацетамом / 
Огляди літератури, оригінальні дослідження, поглядн на В. В. Шацький, А. А. Гудима, Л. Я. Федонюк // Здобутки клінічної і експериментальної медицини. - 2019. - № 4. С. 144-153.

7. Динаміка антиоксидантно-прооксидантного балансу в стінці тонкої кишки під впливом артеріального джгута і реперфузії кінцівки / І. Стрельбицька, А. Гудима, P. Максимів, І. Горбань : матеріали XXII Міжнародного медичного конгресу студентів та молодих вчених, 2325 квітня 2018 р., Тернопіль. - Тернопіль : Укрмедкнига, 2018. - C. 273-274.

8. Стахів О. В. Вплив гострої крововтрати, ускладненої ішемією-реперфузією кінцівки, на активність процесів ліпідної пероксидації у легенях та їх корекція карбацетамом / О. В. Стахів, Р. В. Максимів // Вісник медичних і біологічних досліджень. - 2020. - № 3 (5). - С. 108-114.

9. Атлас селезёнки (видовые особенности у человека и млекопитающих животных) : монография / Н. С. Федоровская [и др.]. - Киров: Аверс, 2011. - 134 с.

10. Максимів Р. В. Динаміка балансу антиоксидантно-прооксидантних механізмів у внутрішніх органах під впливом артеріального джгута і реперфузії кінцівки / Р. В. Максимів, А. А. Гудима, В. М. Сидоренко // Шпитальна хірургія. Журнал імені Л. Я. Ковальчука. - 2017. № 1. - C. 37-44.

11. Tourniquets and occlusion: the pressure of design / P. L. Wall, D. C. Duevel, M. B. Hassan [et al.] // Mil. рроблему, випадок з практики, короткі повідомлення Med. - 2013. - Vol. 178 (5). - P. 578-587. DOI: 10.7205/ MILMED-D-12-00490.

12. Доклінічні дослідження лікарських засобів : метод. рек.; за ред. О. В. Стефанова. - К. : Авіценна, 2001. -528 c.

13. Van der Spuy L. Complications of the arterial tourniquet / L. Van der Spuy // South Afr. J. Anaesth. Analg. 2012. - Vol. 18 (1). - P. 14-18.

14. Wright G. Whould civilian pre-hospital emergency care provision include tourniquets for the management of uncontrolled traumatic haemorrhage? / G. Wright, V. S. Mcdonald, V. G. Smith // Australasian Journal of Paramedicine. - 2015. - Vol. 12 (4). - P. 1-5.

15. Волошин М. В. Будова селезінки (огляд літератури) / М. В. Волошин // Морфологія. -2014. - Т. 14, № 1. C. 8-15.

16. Косырева А. М. Морфофункциональная характеристика иммунной системы самцов и самок крыс Вистар / А. М. Косырева, Е. Ю. Симонова, О. В. Макарова // Иммунология. - 2011. - № 32. - С. 81-84.

17. Cesta M. F. Normal structure, function and histology of spleen / M. F. Cesta // Toxicol. Pathol. - 2006. Vol.34(5).-P.455-456.DOI:10.1080/01926230600867743.

18. Steiniger B. Human spleen microanatomy: why mice do not suffice / B. Steiniger // Immunology. - 2015. Vol. 145 (3). - P. 334-346. DOI: 10.1111/imm.12469.

\section{REFERENCES}

1. Elster, E., Frank, K.B., \& Todd, E.R. (2013). Implications of combat casualty care for mass casualty events. JAMA, 310 (5), 475-476.

2. Efficacy of prehospital application of tourniquets and hemostatic dressings to control traumatic external hemorrhage. Retrieved from: https://trid.trb.org/ view/1489860.

3. Televiak, A.T., Selskyi, P.R., Veresiuk, T.O., \& Slyva, A.F. (2018). Analiz zmin struktury miazovoyi tkanyny ta biokhimichnykh pokaznykiv syrovatky krovi pry rozvytku ishemichno-reperfuziinoho syndromu (eksperymentalne doslidzhennia) [Analysis of changes in the structure of muscle tissue and biochemical parameters of blood serum in the development of ischemic-reperfusion syndrome (experimental study)]. Proceedings of the $X$ Congress pathologists of Ukraine "Perspektyvy rozvytku suchasnoi patolohiis - "Prospects for the development of modern pathology". Ivano-Frankivsk [in Ukrainian].

4. Volotovska, N.V., Nhokwara, T.C., \& Zhulkevych, I.V. (2019). Changes in the glutathione systems activity of internal organs in the first hours of experimental limb ischemia-reperfusion syndrome, combined with blood loss and mechanical injury. Zdobutky klinich. i eksperym. medytsyny Achievements of Clinical and Experimental Medicine, 1, 23-27. Retrieved from: https://doi.org/10.11603/1811-2471.2019. v0.i1.10043.

5. Horban, I.I. (2020). Vplyv hostroi krovovtraty, uskladnenoi ishemiieiu-reperfuziieiu kintsivky, na antyoksydantno-prooksydantnyi balans pechinky ta yoho korektsiia karbatsetamom [The effect of acute blood loss complicated by limb ischemia-reperfusion on the antioxidant-prooxidant

balance of the liver and its correction by carbacetam]. Zdobutky klinichnoi i eksperymentalnoi medytsyny - Achievements of Clinical and Experimental Medicine, 2, 93-100 [in Ukrainian].

6. Shatsky, V.V., Gudyma, A.A., \& Fedoniuk, L.Y. (2019). Dynamika antyoksydantno-prooksydantnoho balansu kirkovoho i mozkovoho shariv nyrky pislia hostroi krovovtraty, uskladnenoi ishemiieiu-reperfuziieiu kintsivky, ta yoho korektsiia karbatsetamom [Dynamics of antioxidant-prooxidant balance of renal cortex and medulla after acute blood loss complicated by ischemia-reperfusion of the extremity, and its correction with carbacetam]. Zdobutky klinichnoi $i$ eksperymentalnoi medytsyny - Achievements of Clinical and Experimental Medicine, 4, 144-153 [in Ukrainian].

7. Strelbytska, I., Hudyma, A., Maksymiv, R., \& Horban, I. (2018). Dynamika antyoksydantno-prooksydantnoho balansu $v$ stintsi tonkoi kyshky pid vplyvom arterialnoho dzhhuta i reperfuzii kintsivky [Dynamics of antioxidant-prooxidant balance in the wall of the small intestine under the influence of arterial tourniquet and limb reperfusion]. Proceedings of the XXII Mizhnarodnoho medychnoho konhresu studentiv ta molodykh vchenykh - International Medical Congress of Students and Young Scientists. Ternopil: Ukrmedknyha [in Ukrainian].

8. Stakhiv, O.V., \& Maksymiv, R.V. (2020). Vplyv hostroi krovovtraty, uskladnenoi ishemiieiu-reperfuziieiu kintsivky, na aktyvnist protsesiv lipidnoi peroksydatsii u leheniakh ta yikh korektsiia karbatsetamom [Influence of acute blood loss complicated by limb ischemia-reperfusion on the activity of lipid peroxidation processes in lungs and their correction with carbacetam]. Visnyk medychnykh $i$ biolohich- 
Огляди літератури, оригінальні дослідження, погляд на проблему, випадок з практики, короткі повідомлення nykh doslidzhen - Bulletin of Medical and Biological Research, 3 (5), 108-114 [in Ukrainian].

9. Fedorovskaya, N.S. (2011). Atlas selezonki (vidovyye osobennosti u cheloveka i mlekopitayushchikh zhivotnykh): monografiya [Atlas of the spleen (specific features in humans and mammals): monograph]. Kirov: Avers [in Russian].

10. Maksymiv, R.V., Hudyma, A.A., \& Sydorenko, V.M. (2017). Dynamika balansu antyoksydantno-prooksydantnykh mekhanizmiv u vnutrishnikh orhanakh pid vplyvom arterialnoho dzhhuta i reperfuzii kintsivky [Dynamic of balance of antioxidant-prooxidant mechanism in internal organs under the influence of blood harnesses and limb reperfusion]. Shpytalna khirurhiia. Zhurnal imeni L. Ya. Kovalchuka- Hospital Surgery. Journal named after L. Ya. Kovalchuk, 1, 37-44 [in Ukrainian].

11. Wall, P.L., Duevel, D.C., Hassan, M.B., Welander, J.D., Sahr, S.M., \& Buising, C.M. (2013). Tourniquets and occlusion: the pressure of design. Mil. Med., 178 (5), 578-587. DOI: 10.7205/MILMED-D-12-00490.

12. Stefanov, O.V. (Ed.). (2001). Doklinichni doslidzhennia likarskykh zasobiv: metod. rek. [Preclinical studies of drugs: guidelines]. Kyiv: Avitsenna [in Ukrainian].

13. Van der Spuy, L. (2012). Complications of the arterial tourniquet. South Afr. J. Anaesth. Analg., 18 (1), 14-18.

14. Wright, G., Mcdonald, V.S., \& Smith, V.G. (2015). Whould civilian pre-hospital emergency care provision include tourniquets for the management of uncontrolled traumatic haemorrhage? Australasian Journal of Paramedicine, 12 (4), 1-5.

15. Voloshyn, M.V. (2014). Budova selezinky (ohliad literatury) [Structure of the spleen (literature review)]. Morfolohiia - Morphology, 14, 1, 8-15 [in Ukrainian].

16. Kosyreva, A.M., Simonova, Ye.Yu., \& Makarova, O.V. (2011). Morfofunktsionalnaya kharakteristika immunnoy sistemy samtsov i samok krys Vistar [Morphofunctional characteristics of the immune system of male and female Wistar rats]. Immunologiya - Immunology, 32, 81-84 [in Russian].

17. Cesta, M.F. (2006). Normal structure, function and histology of spleen. Toxicol. Pathol., 34 (5), 455-456. DOI: 10.1080/01926230600867743.

18. Steiniger, B. (2015). Human spleen microanatomy: why mice do not suffice. Immunology, 145 (3), 334-346. DOI: $10.1111 / \mathrm{imm} .12469$.

\title{
ДИНАМИКА АКТИВНОСТИ ПРОЦЕССОВ ЛИПИДНОЙ ПЕРОКСИДАЦИИ В СЕЛЕЗЕНКЕ ПОД ВЛИЯНИЕМ ОСТРОЙ КРОВОПОТЕРИ, ОСЛОЖНЕННОЙ ИШЕМИЕЙ-РЕПЕРФУЗИЕЙ КОНЕЧНОСТИ, И ЕЕ КОРРЕКЦИЯ КАРБАЦЕТАМОМ
}

\author{
○И. В. Яворская, И. Я. Господарский
}

Тернопольский национальный медицинский университет имени И. Я. Горбачевского МОЗ Украины

РЕзЮМЕ. Применение турникета в условиях массивного наружного кровотечения является основным средством спасения раненых и пострадавших в результате ранений магистральных сосудов конечностей с безопасным сроком до двух часов. Одновременно доказано, что двухчасовая полная ишемия-реперфузия конечности вызывает активацию процессов пероксидного окисления липидов (ПОЛ) во внутренних органах, в условиях острой кровопотери способствует развитию полиорганной недостаточности. Однако в условиях острой кровопотери, осложненной ишемией-реперфузией конечности, интенсивность ПОЛ практически не исследована в селезенке.

Цель - выяснить влияние острой кровопотери, осложненной ишемией-реперфузией конечности, на активность процессов ПОЛ в селезенке и оценить корректирующую эффективность карбацетама.

Материал и методы. В экспериментах использовано 108 нелинейных крыс-самцов массой 200-220 г. Все эксперименты выполнены под тиопентал-натриевым наркозом. У животных моделировали ишемию-реперфузию конечности, острую кровопотерю и сочетали эти повреждения. В отдельной группе проводили коррекцию выявленных нарушений карбацетамом. Через 1 и 2 часа, а также через 1, 7 и 14 суток в селезенке подопытных животных определяли содержание диеновых конъюгатов (ДК) и реагентов к тиобарбитуровой кислоте (ТБК-активные продукты ПОЛ).

Результаты. Установлено, что в условиях ишемии-реперфузии конечности, острой кровопотери и их сочетания имеет место усиление процессов липидной пероксидации в селезенке, что проявляется ростом содержания ДК и ТБК-активных продуктов ПОЛ. Общей закономерностью интенсификации ПОЛ в селезенке является достижение максимального уровня через 1 сутки с последующим снижением. Дополнительное осложнение острой кровопотери ишемией-реперфузией конечности сопровождается существенно большим ростом интенсивности ПОЛ в селезенке, по сравнению с их отдельным моделированием. В условиях коррекции карбацетамом у животных с острой кровопотерей, осложненной ишемией-реперфузией конечности, активность процессов липидной пероксидации в селезенке уменьшалась, что через 7 и 14 суток проявлялось существенно более низким содержанием исследуемых показателей ПОЛ. Итак, карбацетам проявляет системное антиоксидантное влияние, что ставит его в ряд перспективных средств снижения проявлений оксидативных нарушений во внутренних органах в условиях острой кровопотери, осложненной ишемией-реперфузией конечности, и профилактики развития полиорганной недостаточности.

Выводы. Ишемия-реперфузии конечности способствует усилению процессов липидной перокисидации в селезенке, обусловленных острой кровопотерей, сопровождается статистически достоверно большим ростом содержания ДК через 2 часа и 14 суток эксперимента и ТБК-активных продуктов ПОЛ - через 1, 7 и 14 суток, по сравнению 
Огляди літератури, оригінальні дослідження, погляд на проблему, випадок з практики, короткі повідомлення с животными, которым моделировали только острую кровопотерю. Применение карбацетама в дозе 5 мг·кг внутрибрюшинно проявляет выраженное антиоксидантное влияние и через 7 и 14 суток способствует меньшему росту в селезенке ДК и ТБК-активных продуктов ПОЛ.

КЛючЕВЫЕ СЛОВА: острая кровопотеря; ишемия-реперфузия конечности; селезенка; липидная пероксидация; карбацетам.

\section{DYNAMICS OF ACTIVITY OF LIPID PEROXIDATION PROCESSES IN THE SPLEEN UNDER THE INFLUENCE OF ACUTE BLOOD LOSS, COMPLICATED BY ISCHEMIA- REPERFUSION OF THE LIMB AND ITS CORRECTION WITH CARBACETAM}

\section{Horbachevsky Ternopil National Medical University}

OI. V. Yavorska, I. Ya. Hospodarsky

SUMMARY. The use of a tourniquet in conditions of massive external bleeding is the main means of rescuing wounded and injured in conditions of injuries of the main vessels of the extremities with a safe period of up to two hours. At the same time, it has been proven that two-hour complete ischemia-reperfusion of the limb causes activation of lipid peroxidation (LPO) processes in the internal organs, which in the conditions of acute blood loss contributes to the development of multiple organ failure. However, under conditions of acute blood loss complicated by ischemia-reperfusion of the limb, the intensity of LPO has not been studied in the spleen.

The aim - to determine the effect of acute blood loss complicated by limb ischemia-reperfusion on the activity of LPO processes in the spleen and to evaluate the corrective efficacy of carbacetam.

Material and Methods. 108 nonlinear male rats weighing 200-220 g were used in the experiments. All experiments were performed under thiopental-sodium anesthesia. In animals, limb ischemia-reperfusion and acute blood loss were simulated and these lesions were combined. In a separate group, the detected disorders were corrected with carbacetam. After 1 and 2 hours, as well as after 1, 7 and 14 days in the spleen of experimental animals, the content of diene conjugates (DC) and the content of reagents to thiobarbituric acid (TBA-active products of LPO) were determined.

Results. It was established that under conditions of ischemia-reperfusion of the limb, acute blood loss and their combination there is an increase in lipid peroxidation in the spleen, which is manifested by an increase in the content of DC and TBA-active products of LPO. The general pattern of intensification of LPO in the spleen is to reach the maximum level in 1 day, followed by a decrease. An additional complication of acute blood loss by limb ischemia-reperfusion is accompanied by a significantly greater increase in the intensity of LPO in the spleen, compared with their individual simulation. Under the conditions of carbacetam correction in animals with acute blood loss complicated by ischemia-reperfusion of the limb, the activity of lipid peroxidation processes in the spleen decreased, which after 7 and 14 days was manifested by a significantly lower content of the studied LPO. Thus, carbacetam has a systemic antioxidant effect, which puts it in a number of promising ways to reduce the manifestations of oxidative disorders in the internal organs in conditions of acute blood loss complicated by ischemia-reperfusion of the limb, and prevention of poly-organ failure.

Conclusions. Limb ischemia-reperfusion enhances lipid peroxidation processes in the spleen due to acute blood loss, accompanied by a statistically significant increase in DC content after $2 \mathrm{~h}$ and 14 days of the experiment and TBAactive LPO products - after 1, 7 and 14 days compared to animals, which simulated only acute blood loss. The use of carbacetam at a dose of $5 \mathrm{mg} \cdot \mathrm{kg}-1$ intraperitoneally has a pronounced antioxidant effect and after 7 and 14 days promotes less growth in the spleen of DC and TBA-active products of LPO.

KEY WORDS: acute blood loss; ischemia-reperfusion of the limb; spleen; lipid peroxidation; carbacetam.

Отримано12.11.2020 